ホソ研究助成
成果報
Hosokawa Powder Technology Foundation ANNUAL REPORT

17107

\title{
赤血球を鋳型とした機能性ソフト粒子の創製と応用 \\ Fabrication and Application of Functional Soft Particles Using Red Blood Cells as Template
}

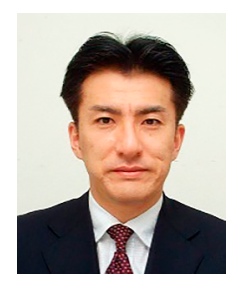

研究代表者 Research leader：新戸 浩幸Ｈiroyuki SHINTO

福岡大学工学部 教授

Faculty of Engineering, Fukuoka University, Professor

E-mail: hshinto@fukuoka-u.ac.jp

抄 録

赤血球を用いて, 種々の形態をもつだけではなく, 赤血球膜上に存在する血液型糖鎖の生物学的機 能をも保持した機能性ソフト粒子の創製を目指した，主な成果として，パラホルムアルデヒドによ る赤血球の化学固定によって, 赤血球膜に対するウシ血清アルブミンの吸着は著しく低減されるが, 血液型糖鎖の認識タンパク質であるレクチンの吸着は変化しないことがわかった.

\begin{abstract}
Using red blood cells (RBCs), we have fabricated functional soft particles, which exhibit not only several kinds of shapes but also biologically functional sugar chains of ABO blood group on the RBC membrane even after chemical fixation. It was found that chemical fixation of RBCs with paraformaldehyde significantly reduces the adsorption amount of bovine serum albumin on an RBC, but hardly affects that of lectins (i.e., proteins that recognize blood type sugar chains).
\end{abstract}

\section{研究背景と目的}

生物には, その微細構造として, 形や配列に 特異性・規則性をもつ種が数多く存在する。近 年,このような生物微細構造を鋳型として金属・ 半導体・高分子などに転写することより, 新規 機能性材料を創造しようとするバイオテンプ レート法が注目されている。例えば, 左巻きの らせん形状を示すスピルリナ(微細藻類の一種) の表面を金属メッキし，得られたマイクロコイ ルを円偏波用デバイスに応用する研究が報告さ
れている (Kamata K., 2014). しかし従来の研 究報告では, 生物微細構造体は鋳型として使用 されるだけで, その構成要素である生体物質(多 糖, タンパク質など) が本来もつ生物学的機能 を活用するという視点がない.

本研究では, 赤血球を鋳型として用いること により, 種々の形態をもつだけではなく, 赤血 球膜上に存在する $\mathrm{ABO}$ 式血液型物質の生物学 的機能（図 1) をも保持した機能性ソフト粒子 の創製を目指した。この血液型物質は単糖 5〜 6 個が結合した糖鎖であり，その末端に位置す 


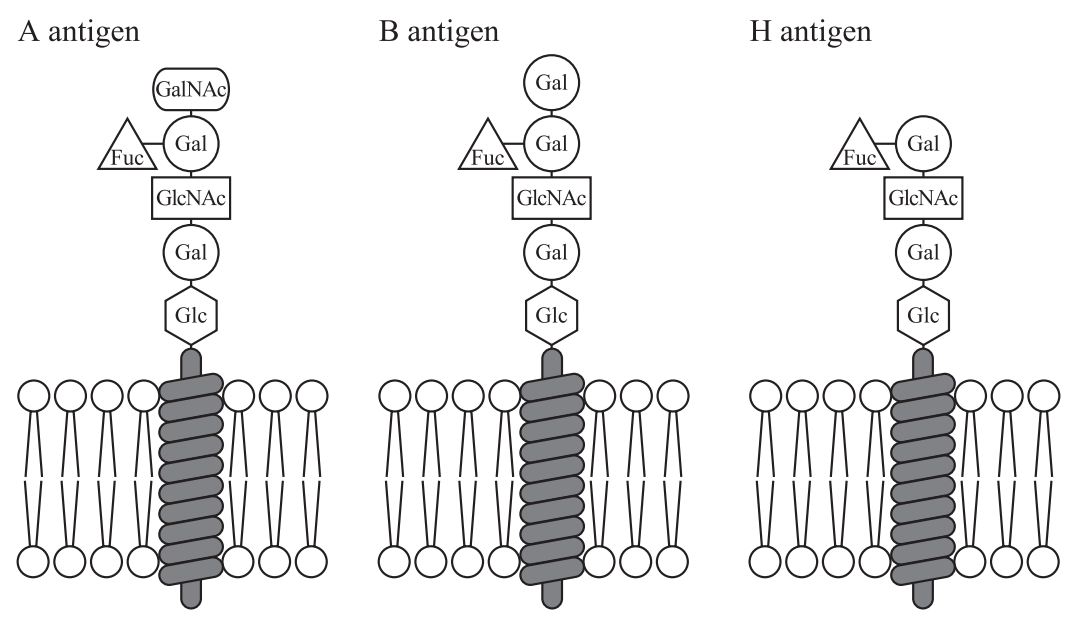

Fig. 1 Schematics of sugar chain structures of ABO blood group.

る糖 1〜2 個の構造の違いよって血液型が決定 される (奈良, 2017). 創製した機能性ソフト 粒子をカラムクロマトグラフィー用充填剤に応 用することを見据えて, $\mathrm{ABO}$ 式血液型糖鎖 3 種を特異的に認識するタンパク質（レクチンな ど）の赤血球に対する吸着挙動を検討した。

\section{研 究 方 法}

\section{1. 赤血球の分離と固定化}

ウサギ保存血液（日本バイオテスト研究所） またはヒツジ保存血液（日本バイオテスト研究 所）から, 遠心分離 $\rightarrow$ 上清液の除去 $\rightarrow$ 細胞ペレッ トの再懸濁を繰り返すことによって, 赤血球を 分離精製した。種々の形態をもつ赤血球を作製 するため, 薬物を添加した後, パラホルムアル デヒドによって細胞膜を温和に化学架橋した (八木, 2007).

\section{2. 赤血球の血液型の決定}

ヒッジの個体を $\mathrm{ABO}$ 式血液型として分類する と, $\mathrm{B}$ 型および $\mathrm{O}$ 型しかいないことがわかって いる. 全 8 頭の個体のヒツジ保存血液（日本バイ オテスト研究所）の血液型を判定するため, オモ テ判定試薬である $\mathrm{ABO}$ スフィア（KTS502C； 鎌倉テクノサイエンス）およびバイオクローン 抗 $\mathrm{A} /$ 抗 B/ 抗 A\&B (111006/112003/113000; オー ソ・クリニカル・ダイアグノスティックス),
ウラ判定試薬であるアファーマジェン (151002; オーソ・クリニカル・ダイアグノスティックス） を用いた。

\section{3. 赤血球膜へのタンパク質の吸着}

固定化赤血球膜上の $\mathrm{ABO}$ 式血液型糖鎖が生 物学的機能を保持しているかどうかを検討する ため, 蛍光標識されたタンパク質 (B 抗原認識 レクチン GS-I, H 抗原認識レクチン UEA-I, またはウシ血清アルブミン（BSA））を最終濃 度 $5 \sim 50 \mathrm{mg} / \mathrm{mL}$ となるように赤血球懸濁液 $\left(1 \times 10^{6} \mathrm{cells} / \mathrm{mL}\right)$ に溶解させて, $4^{\circ} \mathrm{C} て ゙ 60$ 分 間のインキュベーションを行った。 その後, 遠 心分離 $\rightarrow$ 上清液の除去 $\rightarrow$ 細胞ペレットの再懸濁 を合計 3 回行い, 未吸着のタンパク質を除去し た，得られた赤血球サンプルをフローサイトメ トリー解析した。これにより, 化学固定の有無 が血液型糖鎖などに対して及ぼす影響を検討し た。

\section{研究成果}

\section{1. パラホルムアルデヒド固定化赤血球}

通常の赤血球の形は円盤型（図 2 左）である. しかし, 保存血液から分離精製して得られる赤 血球は, ウ二型 (図 2 中央) および球型（図 2 右） を示すものがほとんどであった，ウサギの場合 はウニ型, ヒツジの場合は球型の赤血球が多く 

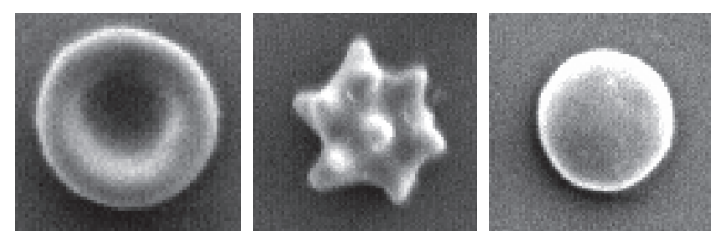

Fig. 2 Scanning electron micrograph (SEM) images of chemically fixed rabbit-RBC with three different shapes: biconcave discocyte, spiculated echinocyte, and sphere, from left to right.

観察された。この主な原因として, 赤血球内の アデノシン三リン酸（ATP）の低下が指摘され ている（水上，1993）.

そこで，赤血球内 ATP を制御することによ り, 赤血球の形態制御を目指した。このため, リン酸緩衝生理食塩水にいくつかの濃度条件で グルコース，イノシン，およびアデニンを添加 し，ヒッジ赤血球をインキュベーションした． この結果，赤血球内 ATP の制御によって赤血 球の形態をある程度制御することが可能である ことがわかった。

\section{2. 赤血球膜ヘタンパク質の吸着}

全 8 頭のヒツジの血液型判定を行ったが，才 モテ判定に扔ける赤血球凝集反応の陰性・陽性 の判断がしばしば困難であり, ある 1 頭を除い て3 種類の判定法による結果がすべて同じとな る個体はなかった。総合的に検討し, 全 8 頭の ヒツジのうち B 型が 2 頭, $\mathrm{O}$ 型が 6 頭という 結論に至った。

\section{3. 赤血球膜ヘタンパク質の吸着}

本実験項目の遂行直前に B 型のヒツジ 2 頭 がともに死んでしまい， B 型赤血球の入手が不 可能となってしまった。このため以下では, O 型赤血球のみを用いた実験結果を示す.

そのままの赤血球（Intact RBC）または化学 固定された赤血球（Fixed RBC）に対する蛍光 標識タンパク質（GS-I, UEA-I, BSA）の吸着質 量の相対值を図 3 に示す. Intact RBCでは, BSA が高い吸着量を示し, GS-I および UEA-I の吸着量はほほ同じでBSAの吸着量の $1 / 2$ 以
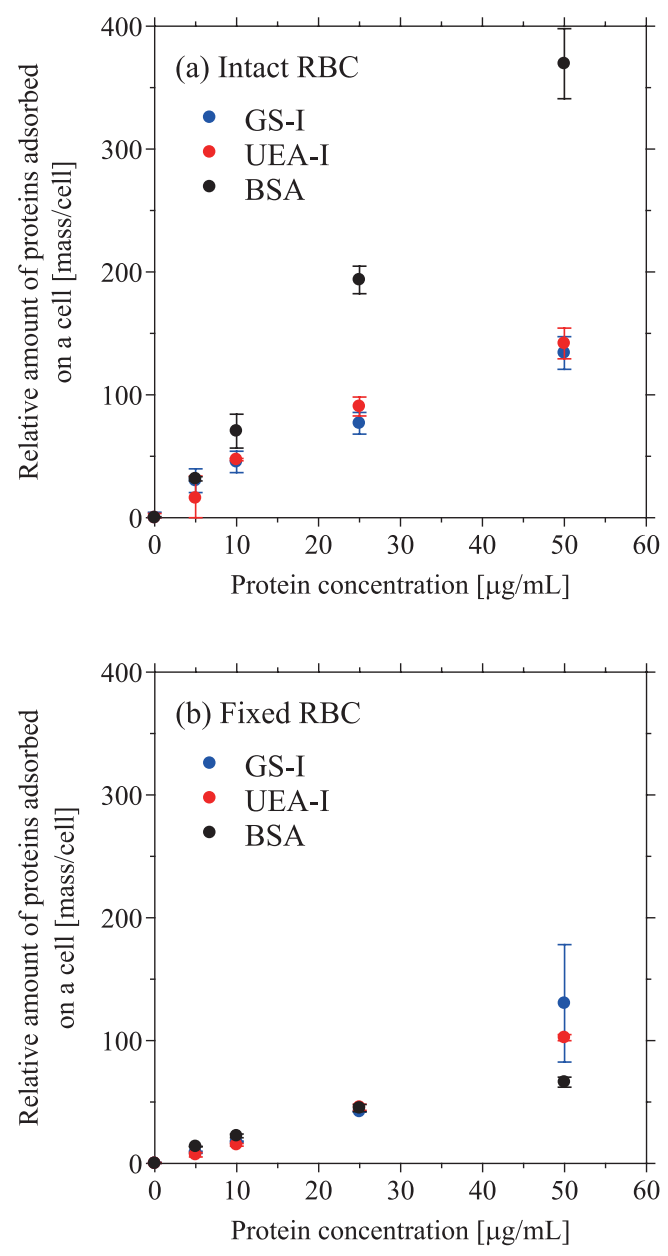

Fig. 3 Relative amount of proteins (GS-I, UEA-I, or BSA) adsorbed on an intact sheep-RBC (a) and a chemically fixed sheep-RBC (b) as a function of protein concentration.

下であった（BSA $>$ UEA-I $=$ GS-I）. 用いた赤 血球は O 型であったため, UEA-I > GS-I > BSA という吸着量の順序を予想していたが，実際の 結果は違っていた。フローサイトメトリーによ る解析結果をよく見ると, やはり $\mathrm{H}$ 抗原認識 レクチンであるUEA-I は O 型の赤血球どうし の凝集を引き起こしていたが，一方，GS-I お よび BSA による O 型赤血球の凝集はほとんど 見られなかった。

Fixed RBC に対する GS-I および UEA-I の吸 着量は, Intact RBC に対する吸着量とほほ同じ であった. 一方, BSA の吸着量は赤血球の化学 固定により著しく減少し, GS-I および UEA-I の 吸着量とほぼ同じになった。これらのタンパク 
質による Fixed RBC どうしの凝集は観察されな かった。

以上の結果は, (1) 赤血球のパラホルムアル デヒド固定により, 赤血球膜上に存在するタン パク質の構造や赤血球膜自体の構造が変化する こと，(2）膜タンパク質に結合している血液型 糖鎖は，パラホルムアルデヒドの影響を受けに くいこと，を示唆している，今後，血液型糖鎖 の認識タンパク質 (本研究では GS-I と UEA-I) を分離精製することを目的として赤血球を利用す るためには，さらに詳細な検討が不可欠である.

\section{外部 発表成果}

\section{論文発表}

1. Seto H., Saiki A., Kamba S., Kondo T., Hasegawa M., Miura Y., Hirohashi Y., Shinto H., Amplification of sensor signals from metal mesh device with fine periodic structure, Analytical Sciences, 35 (2019) 619-623.

https://doi.org/10.2116/analsci.18P498

2. Shinto H., Fukasawa T., Yoshisue K., Tsukamoto N., Aso S., Hirohashi Y., Seto H., Effect of interfacial serum proteins on the cell membrane disruption induced by amorphous silica nanoparticles in erythrocytes, lymphocytes, malignant melanocytes, and macrophages, Colloids and Surfaces B: Biointerfaces, 181 (2019) 270-277. https://doi.org/10.1016/j.colsurfb.2019.05.067

3. Shinto H., Fukasawa T., Yoshisue K., Seto H., Kawano T., Hirohashi Y., Effect of exposure temperature on the cell membrane disruption induced by amorphous silica nanoparticles in erythrocytes, lymphocytes, and malignant melanocytes, Advanced Powder Technology, 31 (2020) 835-842.

https://doi.org/10.1016/j.apt.2019.12.001

\section{参考文献}

Kamata K., Piao Z., Iyoda T., Biotemplating process for 3D structured materials, Nippon Gomu Kyokaishi, 87 (2014) 140-145. https://doi.org/10.2324/gomu.87.140 水上 茂樹, 赤血球の生化学 第 2 版, 東京大学出版会, 1993, pp. 5-6, ISBN: 4130632094.

奈良信雄 (監修), ぜんぶわかる血液・免疫の事典, 成 美堂, 2017,pp. 34-35, ISBN: 4415322646.

八木史郎, “レクチン活性の測定法”, レクチン研究法, 学 会出版センター, 2007, pp. 57-77, ISBN: 4762230545.

\section{口頭・ポスター発表}

1. 新戸 浩幸, 瀧口未歩, 泊健人, 廣橋由美子, 瀬戸弘一，“酵母細胞に対するナノ粒子の 付着・取込と毒性のフローサイトメトリー 解析”，化学工学会第 83 年会（Osaka, March 13-15, 2018) N117.

2. 新戸 浩幸, “界面プロセス工学から見た粒 子・細胞間相互作用”，化学工学会九州支部 特別講演会（Fukuoka, May 25, 2018）.

3. 新戸 浩幸, “液相中の種々の細胞に対する 粒子の付着, 取込, 毒性”, H30 年度東北大 学電気通信研究所共同プロジェクト研究会 微粒子一流体混成系がもたらす多様な機能 性（Sendai, Sept. 6, 2018).

4. 新戸 浩幸, 塚本 七海, 中島 可奈英, 廣橋 由 美子，瀬戸弘一，“フローサイトメトリーお よびコロイドプローブ原子間力顕微鏡法によ る細胞一粒子間相互作用の評価”, 第 69 回コ ロイドおよび界面化学討論会（Tsukuba, Sept. 18-20, 2018) 2E01.

5. 熊谷理奈, 増田 優太, 久保 幸毅, 東 将大, 深澤 智典, 廣橋 由美子, 瀬戸 弘一, 新戸 浩幸, “シリカ粒子の溶血作用のメカニズム 解明”，化学工学会第 84 年会（Tokyo, March 13-15, 2019) G317.

6. 兒玉 碧, 増田 優太, 廣橋 由美子, 瀬戸 弘一, 
新戸 浩幸, “糖鎖修飾粒子のマクロファー ジへの付着・取込に対する単一粒子レベル での観測”, 化学工学会第 84 年会 (Tokyo, March 13-15, 2019) PC232.

7. 東納 拓海, 永岡 亜季子, 山本眞唯, 高寄 覀祐, 瀬戸 弘一, 廣橋 由美子, 新戸 浩幸, “触 媒反応を利用した糖鎖高分子の作製および タンパク質結合性評価”, 化学工学会第 84 年会（Tokyo, March 13-15, 2019） PC258.

8. 新戸 浩幸, 塚本 七海, 麻生 早紀, 兒玉 碧, 増田 優太, 廣橋由美子, 瀬戸弘一, “フロー サイトメトリーおよびコロイドプローブ原 子間力顕微鏡法による機能性粒子の細胞親 和性の評価”, 粉体工学会 2019 年度春期研 究発表会（Tokyo, May 9-10, 2019）S-13.

9. 増田 優太, 熊谷 理奈, 久保 幸毅, 東 将大,
深澤 智典, 瀬戸 弘一, 廣橋 由美子, 新戸 浩幸, “シリカ粒子による赤血球の膜破壊の メカニズム解明”, 第 56 回化学関連支部合 同九州大会（Kitakyushu, July 13, 2019）CE2-045.

10. 兒玉 碧, 増田 優太, 廣橋 由美子, 瀬戸弘一, 新戸 浩幸, “マクロファージに対する糖鎖 修飾粒子の付着・取込のフローサイトメト リ一解析”, 第 56 回化学関連支部合同九州 大会（Kitakyushu, July 13, 2019） CE-2-044.

11. 東納 拓海, 永岡 亜季子, 山本眞唯, 高寄 亜祐, 瀬戸弘一, 廣橋由美子, 新戸浩幸, “マ クロファージに対する糖鎖修飾粒子の付着・ 取込のフローサイトメトリー解析”, 第 56 回化学関連支部合同九州大会 (Kitakyushu, July 13, 2019） CE-2-047. 